\title{
Essais
}

ESSAIS

Revue interdisciplinaire d'Humanités

Hors-série 4 | 2018

Stanley Kubrick

\section{Stanley Kubrick and Hieronymus Bosch: In The Garden of Earthly Delights}

\section{Dijana Metlić}

\section{(2) OpenEdition \\ 1 Journals}

\section{Electronic version}

URL: http://journals.openedition.org/essais/633

DOI: 10.4000/essais.633

ISSN: 2276-0970

\section{Publisher}

École doctorale Montaigne Humanités

\section{Printed version}

Date of publication: 1 July 2018

Number of pages: 105-123

ISBN: 979-10-97024-04-8

ISSN: 2417-4211

\section{Electronic reference}

Dijana Metlić, "Stanley Kubrick and Hieronymus Bosch: In The Garden of Earthly Delights », Essais

[Online], Hors-série 4 | 2018, Online since 01 December 2019, connection on 16 December 2019. URL :

http://journals.openedition.org/essais/633; DOI : 10.4000/essais.633 


\section{Stanley Kubrick and Hieronymus Bosch: In The Garden of Earthly Delights}

\section{Dijana Metlić}

In 1999 Stanley Kubrick completed his last film, Eyes Wide Shut, based on the 1926 book Traumnovelle by Austrian writer Arthur Schnitzler. Set in early $20^{\text {th }}$ century Vienna, Schnitzler's story analyses a marital crisis and infidelity, psychological pressures caused by dreams and phantasms, and offers potential solutions for overcoming such unpleasant situations. Kubrick made a geographical and temporal shift to late-twentieth-century New York, otherwise remaining faithful to the original novella. He focuses on the relationship between prosperous doctor Bill Harford and his charming wife Alice, who suddenly shatters their family harmony by confessing her past temptation to commit adultery. By revealing her hidden sexual desires that are obviously not properly fulfilled in the marital bed, she causes a psychological crack in her husband, who will have to suffer a painful process of self-discovery to recover his reputation of a doctor, father and family man.

Eyes Wide Shut can be understood as essentially an intimate film about the unbearable lightness of (domestic) being. It questions sexual confidence on which family life depends, and tries to highlight the importance of conjugal trust that is easily shaken by the world's incitements. Signified as a millennial work, released in the final year of the previous century, Eyes Wide Shut seems to summarise Kubrick's thoughts on crucial existential issues like fidelity, desire, jealousy, sex, and death. It deals with romance and passion, rethinking the old presumption that women want love, and men want sex. ${ }^{1}$ It forces the spectator to consider the reasons for the (un)expected weakening of erotic compulsion in marriage and the fading of everlasting love at first sight. It looks at sex as an important marital driving force whose unifying powers must not be forgotten and underrated. As Celestino Deleyto pointed out, Bill's sexual odyssey taught him a lesson that making love in marriage can be about

1 Further on romantic and passionate love, consult: Anthony Giddens, The Transformation of Intimacy, Stanford University Press, 1992, p. 37-87. 
enjoying more freedom in the flesh of his own wife Alice. "The measure of their reconciliation will depend on their ability to turn it [sex] into the joyous, healthy, and pleasurable affair." ${ }^{2}$

Kubrick had been preoccupied with Traumnovelle since at least $1968 .^{3}$ In the first place, he admired the Viennese author, expressing esteem for his work in a 1960 interview: "It's difficult to find any writer who understood the human soul more truly and who had a more profound insight into the

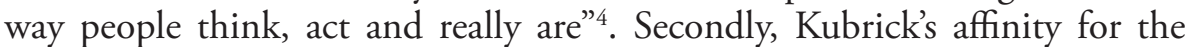
stylistic beauty of the film La Ronde (1950), based on a Schnitzler novel and directed by Max Ophüls, was also well acknowledged. This Austrian film maker, according to Kubrick, never "received the critical appreciation he deserved"s. Finally, Kubrick's early interest in Sigmund Freud ${ }^{6}$ was confirmed by his desire to direct "a contemporary story that really gave a feeling of the times, psychologically, sexually"'. In 1980 Kubrick sent Schnitzler's novel to screenwriter Michael Herr who said that "it intrudes on the concealed roots of Western erotic life like a laser, suggesting discreetly, from behind its dream cover, things that are seldom even privately acknowledged, and never spoken of in daylight" ${ }^{8}$. It is not surprising that the director waited for almost three decades to develop this project, although Warner Brothers announced its production just after the premiere of A Clockwork Orange (1971). ' Therefore, Eyes Wide Shut unintentionally became Kubrick's final and most personal work, the one that underscores the importance of harmonious marriage for the regularity and stability of daily existence. As Michel Ciment remarked, this film "is focused on the most intimate aspects of our individuality, the problems of the couple, the crisis of identity" 10 .

2 Celestino Deleyto, "1999, A Closet Odyssey: Sexual Discourses in Eyes Wide Shut", Atlantis, 28.1, June 2006, p. 29-43.

3 Kubrick's fascination with Schnitzler was analysed in many articles. Consult: Lucy Scholes and Richard Martin, "Archived Desires: Eyes Wide Shut" in Tatjana Ljujić, Peter Krämer and Richard Daniels (eds), Stanley Kubrick: New Perspectives, London, Black Dog Publishing, 2015, p. 344-356; Ernesto R. Acevedo-Munoz, "Don't look now: Kubrick, Schnitzler and 'The unbearable agony of desire", Literature Interpretation Theory, v. 13, April 2002, p. 117-137; James Naremore, On Kubrick, London, British Film Institute, 2014, p. 223; Peter Loewenberg, "Freud, Schnitzler and Eyes Wide Shut" in Geoffrey Cocks (eds.), Depth of Field: Stanley Kubrick, Film, and the Uses of History, Wisconsin, The University of Wisconsin Press, 2006, p. 255-279; Michel Ciment, op. cit., p. 259.

4 Castle (ed.), The Stanley Kubrick Archives, Köln, Taschen, 2008, p. 482.

5 Alexander Walker, Stanley Kubrick, Director: A Visual Analysis, New York, London, W. W. Norton and Company, 2000, p. 14.

6 See: Naremore, op. cit., p. 228-231; Michel Ciment, Kubrick: The Definitive Edition, New York, Faber and Faber, 2003, p. 259-260.

7 Alison Castle (ed.), op. cit., p. 482.

8 Michael Herr, Kubrick, New York, Grove Press, 2000, p. 8.

9 See announcement entitled Kubrick drama from Kine Weekly, issue dated 8 May 1971, reprinted in: Alison Castle (ed.), op. cit., p. 482.

10 Ciment, op. cit., p. 259. 
Talking with Ciment, Kubrick explained that Rhapsody: A Dream Novel is a difficult book that "explores the sexual ambivalence of a happy marriage, and it tries to equate the importance of sexual dreams and might-have-beens with reality" ${ }^{11}$. The appeal of this story lies in the fact that Kubrick constantly blurred the boundaries between the real and the imaginary, basically relying on the impressions induced by Schnitzler: "Fridolin opened his eyes as wide as possible, passed his hand over his forehead and cheeks and felt his pulse. It scarcely beat faster. Everything was right. He was completely awake"12. These uncertainties contribute to the mysterious atmosphere in the film, making it one of the most incomprehensible and ambiguous works in Kubrick's oeuvre. His sudden death caused silence and left us wondering about the film's hidden meanings. By choosing universal themes such as love and jealousy, commitment and trust, sexual intimacy and sexual immorality, monogamy and lust, Kubrick forced us to seek after the true motivation of his final personal and emotional unmasking. As Ciment pointed out, "Eyes Wide Shut breaks with the past. It no longer evokes a love that remains unrequited but explores the abyss of the psyche in a 'normal' adult couple, where, as in all Kubrick's films, Eros and Thanatos meet"13.

In his book on Kubrick, Thomas Allen Nelson indicated that the disparate narrative elements of Eyes Wide Shut are composed into a three-part unity that metaphorically imitates the musical form of a sonata. ${ }^{14}$ In this paper I will try to establish a link between the film and a different kind of tripartite structure-Hieronymus Bosch's ${ }^{15}$ large triptych The Garden of Earthly Delights,

11 Kubrick in Ciment, p. 156.

12 Arthur Schnitzler, A Dream Story, Los Angeles, Green Integer, 2003, p. 68.

13 Ciment, op. cit., p. 259.

14 Thomas Allen Nelson, Kubrick: Inside a Film Artist's Maze, Bloomington, Indiana University Press, 2000, p. 268.

15 Hieronymus Bosch lived and worked from around 1450 till 1516 in 's-Hertogenbosch, one of the four largest cities of the duchy of Brabant, near the present-day Belgian border. Familiarly known as Jeroen or Joen, he was born as the fourth of five children in the marriage between Antonius van Aken and Aleid van der Mynnen. There is a relatively small number of records about Bosch's life. He left no letters or diaries, and there are only few references to him in the account books of the Brotherhood of Our Blessed Lady. After he married Aleid van der Mervenne (probably in 1481), the daughter of a wealthy merchant, his social status improved and he was admitted to the elite and the clerical inner circle of "sworn brothers" of the Brotherhood of Our Blessed Lady. Members of this fraternity were well educated priests, theologians, lawyers, and doctors, and by 1500 the membership was extended to few architects and painters. Among them was Master Bosch. He was a devout Catholic, led a peaceful, religious life, and left no children. Occasionally he was commissioned by the Brotherhood to produce altarpieces and panels for their chapels. Interest in Bosch's work revived in the late $19^{\text {th }}$ and increased throughout the $20^{\text {th }}$ century, and many different interpretations of his oeuvre appeared. He was called fantastic and capricious (Vasari); painter of frightful and horrid dreams (Lomazzo); creator of strange appearances, spooks and 
made around 1503. My interpretation of Eyes Wide Shut is founded on the three inner scenes of Bosch's painting: Paradise and the Creation of Eve (left wing), Humankind before the Flood (central panel) and Hell (right wing). The Hartfords' harmonious life in a paradisiacal apartment disrupted by Alice's first confession is viewed as a mirror-image of Bosch's left inner wing; the central and the right panels are consulted in the interpretation of the Somerton sequence; in the discussion of Alice's complex verbalised dreamimage (visually designed by artist Chris Baker and never actually filmed), and finally, in an attempt to explain the cycle of Bill's temptations, signalling the risks of secular love and the dangers of surrendering to carnal needs. I will try to demonstrate how both Bosch and Kubrick construct "a didactic, moralising vanitas world picture" 16 , and how they use their unique artistic visions to entertain the viewers and instruct them how to overcome their personal weaknesses through tolerance and love. Encapsulated in the concept of docere et delectare, this phrase refers to Horace and his poem Ars Poetica (19-18 BC) in which he said: "Poets aim either to benefit, or to amuse, or to utter words at once both pleasing and helpful to life". ${ }^{17}$

Although Bosch's impressive masterpiece incorporates numerous individual stories that can hardly be found in Kubrick's film, it relates to the medieval view of the sexual act, most often understood as a testimony of the "man's fall from the state of angels, at best a necessary evil, at worst a deadly $\sin ^{\text {"18 }}$. Unlike the twentieth-century individual who accepted sex as a normal part of the human condition, The Garden of Earthly Delights arguably depicts the sensual life, more precisely the deadly sin of Lust (luxuria). ${ }^{19}$ Although painted in vivid colours and in a surprisingly modern style attractive to spectators, Bosch's work obviously had different intentions. Its aim was not to evoke and praise the utopian, idyllic world of uninterrupted (sexual) freedom ${ }^{20}$, but to show a

phantoms of Hell (Van Mander). One of the earliest interpretations of his triptychs was introduced by Father José de Següenza, who in 1598 wrote: "I should like to show now that his paintings are not at all [absurdities], but like books of great wisdom and art, and if there are any foolish actions, they are ours, not his, and let us say it, it is a painted satire of the sins and inconstancy of men." See: Virginia Pitts Rembert, Hieronymus Bosch, New York, Parkstone, 2012, p. 18. On Bosch's life and work, further read: Carl Linfert, Hieronymus Bosch, New York, Harry N. Abrams, 1972; Stefan Fischer, Jheronimus Bosch, Köln, Taschen, 2016.

16 Stefan Fischer, op. cit., p. 101.

17 "Aut prodesse volunt aut delectare poatae / aut simul et iucunda et idonea dicere vitae", in: Fischer, ibid.

18 Walter Bosing, Hieronymus Bosch: Between Heaven and Hell, Köln, Taschen, 2010, p. 51.

19 Ibid.

20 See: Hans Belting, Hieronymus Bosch: The arden of Earthly Delights, Münich, Prestel, 2016, p. 85-105. The Garden of Earthly Delights has been studied by many scholars who proposed contradictory interpretations of its central panel. Some of them see it as a panorama of paradise lost, while others think of it as a moral warning. Belting interprets it as a vision of humankind in Paradise untouched by the fall. His arguments rely on the thesis proposed by Fraenger in 1948, 
false Paradise whose transient beauty leads mankind to ruin and damnation. ${ }^{21}$ His garden is situated between Eden and Hell, the origin of sin and its punishment. As a common motif in medieval literature, the subject of love and the consequences of irresponsible sexual behaviour came into Kubrick's focus with his final film, his most developed and most mature work, the one that shows the deceptive nature of the outside world and the ephemeral character of sensual pleasures.

According to screenwriter Frederic Raphael, Kubrick refused to agree that the assumptions of marriage, the nature of jealousy and sex, had changed since Schnitzler's time: "Stanley turned a book about Central Europe at the beginning of the century into a modern American story and asks, 'What's the difference?"' 22 Already in 1968, the director claimed that the basic love relationship is too deeply ingrained in the man's psyche, and that the same sets of pair-bonding instincts (love, jealousy, and possessiveness) still exist even in this allegedly enlightened, and liberated times. ${ }^{23}$ His photo-essay "Jealousy: A Threat to Marriage" published in Look on 24 October 1950, can be perceived as an early proof of his fascination with the primitive emotional programming. Jealousy is "a great source of dramatic conflict" 24 and one of the main driving

who believed that sexuality that inspires mankind in the central panel seems to be pure joy, pure bliss. He also thought that Bosch's triptych was commissioned by the Adamites, a heretic sect which imbued the concept of lust with a paradisiacal innocence. (See: Wilhelm Fraenger, Hieronymus Bosch, $2^{\text {nd }}$ edition, New York, Dorset, 1989) Interpretations offered by De Tolnay (1937), Bax (1949), Baldass (1960) and Vandenbroeck (1980s) are unanimous and rely on Bosch's confirmed religious background, literal sources that inspired him, and his early works. These art historians assume that the triptych represents a nightmare of the humanity and the consequences of ephemeral sensual enjoyment. According to Fischer who follows the above mentioned critics, Bosch's Garden is produced in conjunction with a marriage and, as such, it had to deliver a serious, didactic message. It also reflects the primary religious and moral perspective from which marriage was viewed in Northern Europe. Similarly complex wedding presents were, for example, Botticelli's paintings Primavera and Minerva and the Centaur commissioned by the Medici family in 1482. See: Fischer, op. cit., p. 120. Approaching Eyes Wide Shut through the theories proposed by De Tolnay, Bax, Baldass, and Fischer, I will try to interpret it as a film about the safety of marriage and the power of true love which helps wedded partners to overcome the illicitness of earthly delights.

21 Bosing, op. cit., p. 56. Bosing (following Baldass) notes that the medieval man was very suspicious of material beauty. Behind physical loveliness often lurked death. Many artworks (little ivory carvings and drawings) popular in Bosch's time often displayed embracing lovers, but when turned around reveal rotting corpses. The moralising context of these works was accepted by Bosch in many of his well-known paintings: Ship of Fools, Death of the Miser, Haywain, and The Garden of Earthly Delights.

22 Ciment, op. cit., p. 270.

23 See: Eric Nordern, "Playboy Interview: Stanley Kubrick", in Gene D. Phillips, Stanley Kubrick, Interviews, University Press of Mississippi, 2001, p. 67.

24 Philippe Mather, Stanley Kubrick at Look Magazine, Chicago, Bristol, Intellect, 2013, p. 166. Mather also mentions other jealous characters in Kubrick's films: Rapallo in Killer's Kiss, Humbert Humbert in Lolita, and Lady Lyndon in Barry Lyndon. 
forces behind Bill's desire for revenge. In fact, Kubrick's, Schnitzler's and Bosch's worlds are the same: the only true change concerns religion. Bosch's phantasmagorical visions of punishment can hardly correct the behaviour of individuals living in the "modern godless universe" 25 , or "forbid what is called "living out your fantasies". ${ }^{26}$ As Següenza noted, his Garden had warned us "that wicked blind humanity would not heed the lessons of the Christian faith, but would indulge in a sinful life in a world that must surely end in hell" 27 . Bosing stresses that "to the medieval moralists, it was a woman who took the initiative in leading man into sin and lechery, following the precedent set by Eve"28. The most important role in The Garden of Earthly Delights is given to the first woman, beautiful Eve, whose sexual powers cause Adam's expulsion from Paradise, because he accepts her proposal instead of keeping God's commandment. Kubrick decided to give Alice the role of Eve, who unadvisedly destroys heavenly love in favour of dangerous earthly love whose rules new Adam/Bill is not at all familiar with. Eyes Wide Shut alludes to "Judeo-Christian fall-and-redemption myth" 29 , depicting mankind as given over to sin. "Letting the unconscious go its own way and [experiencing] it as reality" ${ }^{30}$, Kubrick's protagonists prove how even an unconsumed sexual adventure can destroy fidelity and shatter a fragile family peace.

Painted as a marriage gift for Henry III of Nassau Breda (1483-1538) at the beginning of the XVI century, The Garden of Earthly Delights was intended to serve as a nuptial mirror -as a guide to a successful marital alliance and a study of its benefits and hazards. ${ }^{31}$ Commissioned by Engelbert II (14511504) for his successor Henry III, this work possessed suitable moral and religious dimensions while, at the same time, it sought to satisfy the artistic expectations of a sophisticated courtly audience. ${ }^{32}$ Engelbert II suffered from syphilis and probably intended The Garden of Earthly Delights to serve as a

25 Tim Kreider, "Introducing Sociology" in Geoffrey Cocks (eds.), op. cit., p. 286. Kreider suggests that Kubrick's "biblical references serve to show us how bankrupt the Christian ethic is in America by the end of the second millennium AD, how completely it's been co-opted and undermined by commerce". Although I agree with his point, I still argue that Bill's final unmasking and the Harfords' reunion can be understood as Kubrick's last effort to believe in humankind's possibility to change and its capacity to choose true (moral) values.

26 Michel Chion, Eyes Wide Shut, London, BFI, Palgrave Macmillan, 2013, p. 88.

27 Següenza in: Pitts Rembert, op. cit., p. 47.

28 Bosing, op. cit., p. 53.

29 Kreider, op. cit., p. 285.

30 C. G. Jung in: Pitts Rembert, op. cit., p. 101.

31 Fischer, op. cit., p. 101.

32 The Garden of Earthly Delights is mentioned in a journal kept by Italian canon Antonio de Beatis, who in 1517 visited Henry's palace in Brussels. Along with other paintings, the triptych was intended to intrigue and entertain the guests of his court. 
warning for his nephew. Kubrick replaced this medieval panic over syphilis with the actual fear of HIV/AIDS. Bosch's nightmarish visions of Hell correspond to death threats that Bill receives, forcing him to stop his wanderings.

From the very beginning of Eyes Wide Shut, Kubrick creates an impression of the Harfords' perfect life in the garden of Eden, in their huge apartment luxuriously decorated with representations of vegetables, flowers, plants, and domestic pets, painted in bright colours ${ }^{33}$ and recalling Bosch's description of the sixth day of the Creation with God, Adam and Eve (Genesis 1:20-31). The Harfords are new, twentieth-century Adam and Eve, enjoying God's blessing pronounced upon their marriage: "Be fruitful and multiply; fill the earth and subdue it" (Genesis 1:28). In her fair and slender elegance, Alice is already an image of temptation: her enchanting nakedness fascinates spectators before the film's opening credits, attracting Adam's gaze, "the first step towards $\sin ^{\prime \prime}{ }^{4}$. Regardless of the fact that upon his waking Adam directly looks at the newly created woman and turns towards the world of the senses, he has not yet fallen from grace. Kubrick's Bill does not even look at Alice while preparing for Ziegler's Christmas party: she is the only woman for him, the one he adores and loves. It was believed that previous to the Fall, Adam and Eve had copulated without lust, solely for the purpose of producing children. ${ }^{35}$ After the fall, the situation changes: initiated by Alice's first confession, Bill's self-confidence is shaken and the marital fidelity is ruined. His wife's imagined sexual encounter with another man haunts him and expels him from the safety of home.

Various situations subtly prepare Bill's expulsion from Eden: Alice's flirtation with the Hungarian Szavost; Bill's naive conversation with two aggressive models "twined and undulating like two serpents" ${ }^{\text {" }}$; Alice and Bill's first sexual encounter in front of the mirror and finally, her confessed fantasy about the naval officer, that, according to Nelson, reveals "an ordinary female desire for a passionate, illicit sexual experience outside the restrictions of duty and commitment" ${ }^{37}$. On the inner left wing of Bosch's masterpiece, these dangerous situations are symbolically introduced through carefully chosen animals

33 Blue and red dominate Eyes Wide Shut, just like The Garden of Earthly Delights. Although Bosch's symbolic use of colours has not been fully explained, it can be assumed that the red represents temptation, danger, strong energy and libido, while the blue may refer to fear and lovers' grief. It is difficult to fully decipher meanings of Bosch's colours, because they cannot be separated from fruits, animals or creatures which alter their precise connotations. Kubrick also shapes the psychology of his characters and the specific atmosphere of each scene by using red and blue. On the symbolism of Kubrick's colours, consult: Chion, op. cit., p. 15; Deleyto, op. cit., p. 32-33; Julian Rice, Kubrick's Hope: Discovering Optimism from 2001 to Eyes Wide Shut, Maryland, Scarecrow Press, 2008, p. 187-190.

34 Tolnay in: Fischer, op. cit., p. 102.

35 Bosing, op. cit., p. 57.

36 Kreider, op. cit., p. 286.

37 Nelson, op. cit., p. 281. 
(an owl, a horse, a cow, a stag, a deer, reptiles, birds, a giraffe, and a swan), suggesting Adam and Eve's weakness, spiritual blindness, malevolence, sin, temptation, seduction, and arrogance. ${ }^{38}$ The division of the composition into the male side on the left and the female side on the right can be explained in the terms of fifteenth-century art: the wife is assigned to the domestic sphere and the husband to the outside world. ${ }^{39}$ Throughout the film, Alice proves her commitment to the family and home. She is seen in various interiors: in the bedroom, in the kitchen, in the bathroom or the ballroom, and finally in a toy shop. Kubrick never shows her in the street, thus alluding to Bosch's assumption that the woman belongs to her household. Even when innocently flirting with the Hungarian, Alice stresses that she is married, and explicitly rejects to agree with Szavos' observation that "one of the charms of marriage is that it makes deception necessary for both parties" ${ }^{40}$. While making love with her husband, the reflection of Alice's face with her eyes wide open is seen in the mirror. A similar woman (Eve) can be found in Bosch's Hell panel -a reference to the deadly sin of superbia (vanity, pride). This was considered to be the very first of all the deadly sins, the one to which Eve surrendered even in Eden. Therefore, the woman in the Hell panel, facing the mirror, is the negative complement not just of Adam, but also of Eve, as she is portrayed before the fall in the Paradise wing. She is associated with lust because of the devil who puts his arms around her: in almost the same way Bill approaches Alice before they make love after Ziegler's party.

By revealing her unconscious desires to Bill, Alice stops at the safe line and decides not to let her "waking life turn into a nightmare" ${ }^{41}$. Resisting the temptation to disappear with the naval officer, she chooses not to sacrifice everything- her husband, Helena and her whole future -and admits that, at the same time, "her love for Bill was both tender and sad"42. Thus Mrs. Harford confirms that she is aware of the fact that "the wedding is a God-given union of love between man and woman; [it is] a holy sacrament performed under the protection of Christ, both at the spiritual and the practical level" 43 . Bill will acknowledge this after going down a long and hazardous road of enticements, obsessed with Alice's fantasy to which he responds with jealousy and unsettled desire for vengeance.

38 Fischer, op. cit., p. 105.

39 Ibid. As an example of this division into the male and female sides, Fischer specifies Jan van Eyck's Arnolfini Portrait (1434), painted on the occasion of the marriage of the couple. Giovanni Arnolfini is seen in front of the window-signifying the public sphere assigned to the male, while Giovanna Cenami (his wife) is depicted beside their marital bed, as an integral part of her domesticity.

40 Quoted from the film.

41 Nelson, op. cit., p. 283.

42 Quoted from the film.

43 Fischer, op. cit., p. 106. 
The two most important sequences in the development of Eyes Wide Shut are: the secret orgy in Somerton, and Alice's verbalised dream image that was never actually filmed, although Chris Baker made numerous preparatory drawings before the shooting. Kubrick organised these complementary sequences as realistic and dreamlike manifestations of one and the same event, which serves to unmask the doctor, make him face his unconscious fears of infidelity, sexually transmitted diseases and death, and finally show him the way back home. During his nocturnal journey, Bill will pass through Bosch's hell full of temptations before reaching the Somerton mansion where the orgiastic ceremony is staged. Marion reveals her love for the doctor, bringing to light her true longings. Prostitute Domino unsuccessfully tries to seduce Bill who will be saved by Alice's phone call. Nick Nightingale, "compared to the devil, the great tempter, particularly at the Sonata Cafe" 44 allows Bill access to the Somerton ball by giving him the password Fidelio -hinting at his marital fidelity which is about to be shaken. Finally, "Mephisto" Milich, the owner of the costume shop Rainbow, who negotiates "like Shakespeare's infamous merchant of Venice" 45 , provides Bill with a mask and a black cloak with a hood. Thus he prepares the doctor for joining the sexual ritual of a mysterious group whose members know him already, since he was trustfully answering their "house calls" for a while.

Unlike Bosch's nightmarish creatures (a tree-man, a bird-headed monster ${ }^{46}$, a woman with a dice symbolising a prostitute, men tortured on an oversized musical instruments ${ }^{47}$ ) -who are trapped in a situation from which there is no escape, and in which they repeat their activities on earth- Kubrick's hero Bill will be saved from various unintentional and unconsumed (sexual) adventures which will remind him that he is "lucky to be alive". According to Jan Harlan, "Schnitzler's blasphemous concept of depravity was already voyeurism in substance, but Stanley changed this by attempting a pornographic

44 Chion, op. cit., p. 83.

45 Nelson, op. cit., p. 285.

46 The Red Judge from Eyes Wide Shut can be seen as a correlative of a bird-headed monster, sitting on a giant potty chair. Bosch's creature consumes and excretes human bodies simultaneously. The same action can be assigned to the Red Judge. He makes decisions on one's life and death, which is proved by Mandy's "unintentional" overdose, Nick Nightingale's sudden disappearance, or at least two warnings given to Bill. Somerton symbolises Bill's hell: his suffering is psychological and his soul is driven mad by fear, anxiety and distress induced by Alice's fantasy.

47 The church disapproved of secular music. Allowing improvised music-making would only lead to immorality. Bosch depicts a figure being crushed by a giant lute. On his backside a four-line musical staff appears as a tattoo on his skin. Today, musical scores are written on a five-line staff. It remained a complete mystery what the musical notes on the buttocks might have sounded like. Several musical historians have attempted a transcription into modern musical notation and Amelia Hamrick, a student of Oklahoma Christian University, finally transcribed it in 2015. Visit: https://news.artnet.com/art-world/bosch-butt-song-from-hell-309732. 
Hieronymus Bosch type of hell, a fantasy world for faceless voyeurs" ${ }^{38}$. The password Fidelio unlocks the door to an alternative world in which real social circumstances are turned upside down, the arbitrary is set as the new ordering principle, marriage is mocked, and fidelity is nonexistent. Unlike the everlasting garden of Heaven, Somerton becomes an underground kingdom of carnal love that praises lust, but eventually, "the dances will reach their end and dancers fail'; everything will crumble and decay, for Death lies in waiting for all" 49 . The orgy organised in the distant villa for "all the best people" is actually Kubrick's modern vision of Bosch's chaotic hell, dominated by the "evil inn", the term referring to brothels and shady taverns in which listening to secular music, gambling, alcohol, and prostitution led to the sins of lust, anger, vanity, and greed. ${ }^{50} \mathrm{With}$ imaginative freedom, in many weird episodes, Bosch shows the humanity succumbing to vices: the couples circling hand in hand in intimacy around the tree-man's hat symbolise unbridled sex. ${ }^{51}$ The same applies to Kubrick's disguised wealthy patrons and their irresistible courtesans who enjoy their passionate games freely, regardless of the penalties for leading a life of sinful pleasures. This is the fallen humankind, the one that forces Bill to choose between the celestial safety of marriage and the illicitness of the outside world. For the first time, in front of his widely opened eyes, he witnesses that the "man has abandoned the true paradise for the false; he has turned from the Fountain of Life to drink from the fountain of the flesh which (...) intoxicates and brings death" 52 .

Finally, Bill's fear of public humiliation in Somerton is transformed into the substantial fear of the private embarrassment in front of his wife, after her second confession. Her erotic and sexually explicit dream shifts Bill from "Somerton's Old World masked fakery to the honest emotional landscape of Alice's Brave New World of female sexual expression"53. It obviously brings to mind the central panel of The Garden of Earthly Delights, the extensive parklike landscape crowded with nude men and women, who eat giant fruits, play with birds and animals, enjoy the water and above all, indulge in various amorous sports blatantly and without shame. ${ }^{54}$ Enjoying their nakedness and

48 Castle (ed.), op. cit., p. 512.

49 Bosing, op. cit., p. 56.

50 Fischer, op. cit., p. 113.

51 Ibid.

52 Bosing, op. cit., p. 57.

53 Nelson, op. cit., p. 290.

54 Dirk Bax's extensive knowledge of old Dutch literature helped decipher the hidden symbolism of fruits and animals in the central panel. Relying on popular songs, sayings and slang expressions of Bosch's time, the critic noted that many of the fruits serve as metaphors for the sexual organs. "To pluck fruit" was a euphemism for the sexual act. Vandenbroeck associates the cherry with fertility, marriage, and eroticism. The blackberry refers to love; the strawberry signifies the pleasure of love, while song-birds and fish are phallic symbols. See further: Fischer, op. cit., p. 109; Bosing, op. cit., 51. 
sexuality, consistent in their beauty, these lovers merge into Alice's dream as an apotheosis of (appealing) liberated sexuality.

In secular fifteenth-century compositions, these fictive gardens, reminiscent of locus amoenus (pleasant places) which had its roots in the literature of Antiquity, are usually occupied by women and men seen in conversation, playing games or making romantic advances to each other, while music is played and food and drink lie close at hand. ${ }^{55}$ Staged with the help of imagery drawn from the natural world, Bosch intensifies this sensuality to the point of sarcasm. His garden is designed as a secular garden of earthly love, the one in which various aspects of Lust are acted: a couple in a bubble, a group of figures in a red cylindrical object, a pair concealed in a mussel shell, people standing, sitting or resting in physical intimacy, eating, picking fruit or squeezing into vessels, all point to the erotic significance of the scene. When Alice finally wakes up, she recalls the Boschian sinful world, the one in which she felt wonderful, lying in the beautiful garden, stretched out naked in the sunlight, and where "there were all these other people around us, hundreds of them, everywhere. Everyone was fucking and then I was fucking other men, so many, I don't know how many I was with" ${ }^{56}$ Residing at a safe distance from her monotonous, but secure family life, Alice's fantasy is nothing else than the central panel of Bosch's The Garden of Earthly Delights, where lovers enjoy themselves, unaware that Death chases them from behind.

A fantastical setting for lovers in Alice's dream is gradually translated into the closed garden of Somerton, the one in which Bill remains a voyeur because he is incapable of living out his fantasies. Bosch's didactic image was probably inspired by the second part of the well known medieval allegory Roman de la Rose written in the XIII century and modelled on Ovid's Art of Love, in which heavenly and earthly love are irreconcilably opposed as good and evil. ${ }^{57}$ The woman, symbolised by the Rose, connotes only temptation and danger. Alice, Marion, Domino, Mandy, and finally Sally, ultimately signify the power and dominion of women, which in Bosch's association are the complementary of male sinfulness and folly. In the preparatory drawings of Alice's unrecorded dream sequence, Chris Baker shows Alice being kissed by multiple male figures. When the naval officer steps out of a nearby wood towards her, he is shown as part of the trees, as he moves. The most significant series of drawings illustrate Alice and the naval officer making love in a variety of positions on the back

55 Fischer, Ibid. Fischer notes that Bosch deliberately changes the pleasant mood and idyllic atmosphere of late fifteenth-century engravings, such as Large Garden of Love with Chessplayers by Master ES or Small Garden of Love by Master of the Gardens of Love. His enclosed garden contains hidden symbolism indicating poisonous side of the sexual enjoyment.

56 Quoted from the film.

57 Bosing, op. cit., p. 56. Fischer, op. cit., p. 109-110. 
of a galloping horse. ${ }^{58}$ Animals traditionally symbolised the lower appetites of mankind, and personifications of sins are often depicted on the backs of various beasts. ${ }^{59}$ The motifs of riding in a circle and of riding wildly on animals, according to Vandenbroeck, can be traced back to popular fertility rites, to dances of invocation and bindings, and dances of choosing and wooing a partner. They were commonly employed as a metaphor for the sexual act. ${ }^{60}$

In the middle of Bosch's central panel, a caravan of vices has formed a ring around a circular pond in which women are bathing. The acrobatic riders galloping endlessly around this pool are "fools of Venus, blinded and whipped up by their desire for love" ${ }^{61}$ In formal terms, the motif of the circle can be found in each segment of Bosch's triptych: the spherical Earth on the exterior shutters; the convex disc with the owl in the Paradise panel; the round pool with female bathers in the central panel; and the circular brim of the treeman's hat in the Hell-scope, upon which three couples are walking around. The circle is also an important part of Kubrick's aesthetics, an essential device of his narrative structure and an inevitable element of his visual style. The high-angle long shot of people standing or sitting in a circle can be seen in Spartacus, when the freed gladiators gather in the arena to plan their next action; in $D r$. Strangelove's War Room where politicians decide about humanity's fate; Danny endlessly rides his bicycle along the circular corridors of the Overlook hotel in the Shining. From the moment of Alice's first confession, Bill walks around the symbolic mind circles unable to find his way out. When he comes to Somerton he sees the Red Judge choosing disguised beauties from the circle outlined with their bodies. Attendees of the ball encircle Bill accusing him of inconsiderate disturbance of their sexual satisfaction. He is expelled from his paradisiacal home where he will return after a long period of roaming around New York. Although the circle can symbolise the perfection of the cosmos, in the specific situations of Kubrick's and Bosch's worlds, "it may betoken the sinner whose physical desires drive him to wander endlessly and meaninglessly in a circle, without ever reaching a destination"62. After all his wanderings, Bill manages to find his way home, to the eternal heavenly garden, whose harmony must be restored in the marital bed, before any of those unfulfilled sins become true.

A didactic, aphoristic poem based on the marriage proverbs, written in 1450 says: "From bad people one can learn / unchastity, dicing, drinking and swearing / unseasonable drinking and eating / and also to forget days of

58 Lucy Sholes, Richard Martin, op. cit., p. 353. The authors suppose that Kubrick did not shoot the "Alice's dream" sequence because "the cinematic versions risk being whimsical, hazily-lit soft-core pornography".

59 Bosing, op. cit., p. 53.

60 Fischer, Ibid.

61 Ibid.

62 Fischer, op. cit., p. 117. 
fasting / and thus all the commandments / that one should observe before God". ${ }^{63}$ The strange and the astonishing became both Bosch's and Kubrick's means to design visually appealing works through which the spectators could experience a different world, the one that transports them beyond the mundane bounds of daily life. Although it can be argued that at the end of the twentieth century "Kubrick shows himself to be a sexual conservative, since he confirms the importance of monogamous married relations and the heterosexual, nuclear family" ${ }^{64}$, he convincingly proves that "there are very few things in this world that have an unquestionable importance in and of themselves and are not susceptible to debate or rational argument, but the family is one of them" ${ }^{65}$. Ultimately, the viewers will choose their own path: the marriage of two faithful partners with the aim of producing offspring, the uninhibited sexuality of Alice's dream or Somerton's reality or an in-between possibility in which marriage and erotic impulses may be combined. Towards the end of a long, comprehensive study, Erwin Panofsky observed that "the real secret of [Bosch's] magnificent nightmares and daydreams has still to be disclosed. We have bored a few holes through the door of the locked room; but somehow we do not seem to have discovered the key"66. The same conclusion stands for Kubrick's Eyes Wide Shut, a work of art that will inspire new interpretations, sooner or later.

Dijana Metlić

University of Novi Sad Academy of Arts dijana.metlic@gmail.com

\section{Acknowledgments}

My special appreciation goes to Jean-François Baillon and Vincent Jaunas who helped me during my work on this article. I am grateful to the staff of the Museo Nacional del Prado in Madrid, who generously allowed me to use the reproduction of Hieronymus Bosch's large triptych The Garden of Earthly Delights.

63 See: Fischer, op. cit., p. 114.

64 Naremore, op. cit., p. 242.

65 Kubrick in: Eric Nordern, op. cit., p. 67.

66 Erwin Panofsky, Early Netherlandish Painting: Its Origins and Character, Cambridge, Massachusetts, Harvard University Press, 1966, p. 357. 


\begin{abstract}
In 1999 Kubrick's last film, Eyes Wide Shut was released. It was based on the 1926 book Traumnovelle by Arthur Schnitzler. The director focuses on the relationship between prosperous doctor Bill Harford and his beautiful wife Alice, who unadvisedly shatters their conjugal harmony by confessing her past temptation to commit adultery. In my paper I approach Eyes Wide Shut by consulting Hieronymus Bosch's large triptych The Garden of Earthly Delights, painted at the beginning of the XVI century as a marriage gift for Henry III of Nassau Breda. This intricate artwork was intended to serve as a nuptial mirror, as a guide to a successful marital alliance, and a study of its benefits and risks. Similarly, I understand Kubrick's film as an essentially intimate film about the safety of family life and the threats to marriage introduced by the world of incitements. My attempt was to apply three inner scenes of Bosch's masterpiece in the interpretation of Eyes Wide Shut. The Harfords' harmonious life in their paradisiacal apartment disrupted by Alice's first confession is viewed as a mirror-image of Bosch's left inner wing showing Paradise and the Creation of Eve. The central panel (Humankind before the Flood) and the right wing (Hell) are consulted in the interpretation of the Somerton sequence; in the discussion of Alice's complex verbalised dream-image, and finally in an attempt to explain the cycle of Bill's temptations, which signals the risks of secular love and the dangers of surrendering to carnal desires. Examining the narrative content and visual styles of both artworks, I tried to demonstrate how both Bosch and Kubrick construct a didactic, moralising world picture, and how they use their unique artistic expressions to amuse viewers and instruct them how to overcome their personal weaknesses through tolerance and love.
\end{abstract}

\title{
Keywords
}

Stanley Kubrick, Hieronymus Bosch, Eyes Wide Shut, moralizing, painting.

\section{Résumé}

En 1999 parut le dernier film de Stanley Kubrick, Eyes Wide Shut, adapté du livre d'Arthur Schnitzler, La Nouvelle Rêvée, publié en 1926. Le réalisateur explore la relation entre le riche docteur Bill Harford et sa magnifique femme Alice, qui bouleverse leur harmonie conjugale par inadvertance lorsqu'elle avoue avoir envisagé une relation adultère. Dans cet article, nous envisageons Eyes Wide Shut à l'aune du grand triptyque de Jérome Bosch, Le Jardin des délices, peint au début du XVIe siècle, cadeau de mariage pour Henri III de NassauBreda. Cette œuvre complexe devait servir de miroir nuptial, un guide pour parvenir à un mariage réussi, et d'étude quant à ses avantages et ses dangers. De même, nous considérerons l'œuvre de Kubrick comme un film essentiellement intime explorant la sécurité de la vie de famille et les dangers pesant sur le mariage dans un monde aux tentations multiples. Nous interpréterons Eyes Wide Shut à l'aide de trois scènes du chef-d'oeuvre de Bosch. La vie harmonieuse que connait le couple dans son appartement paradisiaque et sa perturbation suite à la confession d'Alice sera mise en parallèle avec le panneau gauche de l'œuvre de Bosch, Le Paradis et la création d'Ève. Le panneau central (L'humanité avant le déluge) et le panneau de droite (L'enfer) permettront d'interpréter la séquence de Somerton, le récit du rêve complexe d'Alice ainsi que le cycle des tentations de Bill, qui évoquent les dangers d'un amour séculaire et les risques de succomber aux désirs charnels. Grâce à l'étude des contenus narratifs et des styles visuels de ces deux oeuvres, nous analyserons la façon dont Bosch et Kubrick élaborèrent chacun une vision du monde didactique et morale, ainsi que leur capacité à tirer profit de leur expression artistique unique pour divertir les spectateurs tout en les instruisant quant aux possibilités de dépasser leurs faiblesses grâce à l'amour et à la tolérance.

Mots-clés

Stanley Kubrick, Hieronymus Bosch, Eyes Wide Shut, moralisme, peinture. 


\section{BIOGRAPHICAL NOTE}

Born in Belgrade, 1978.

In 2012 successfully defended PhD Thesis "From 2001: A Space Odyssey to Eyes Wide Shut: An Analysis of Different Forms of the Image Presence in the Films of Stanley Kubrick" at the Department of Art History, Faculty of Philosophy, University of Belgrade.

In 2013 published a book Stanley Kubrick: Between Painting and Film (Belgrade: Film Centre Serbia) and several articles on Kubrick in Serbian journals. In 2016 attended Stanley Kubrick: A Retrospective, conference at De Montfort University in Leicester, UK. In 2017 published Unmasking the Society: The Use of Masks in Kubrick's Films in Cinergie : il cinema e le altre arti, vol.12.

Currently holds the position of Associate Professor at the Academy of Arts, University of Novi Sad. Teaches history of European Art from Renaissance to the present day.

Fields of research: Modern Art, Historical avant-gardes and Film studies. 

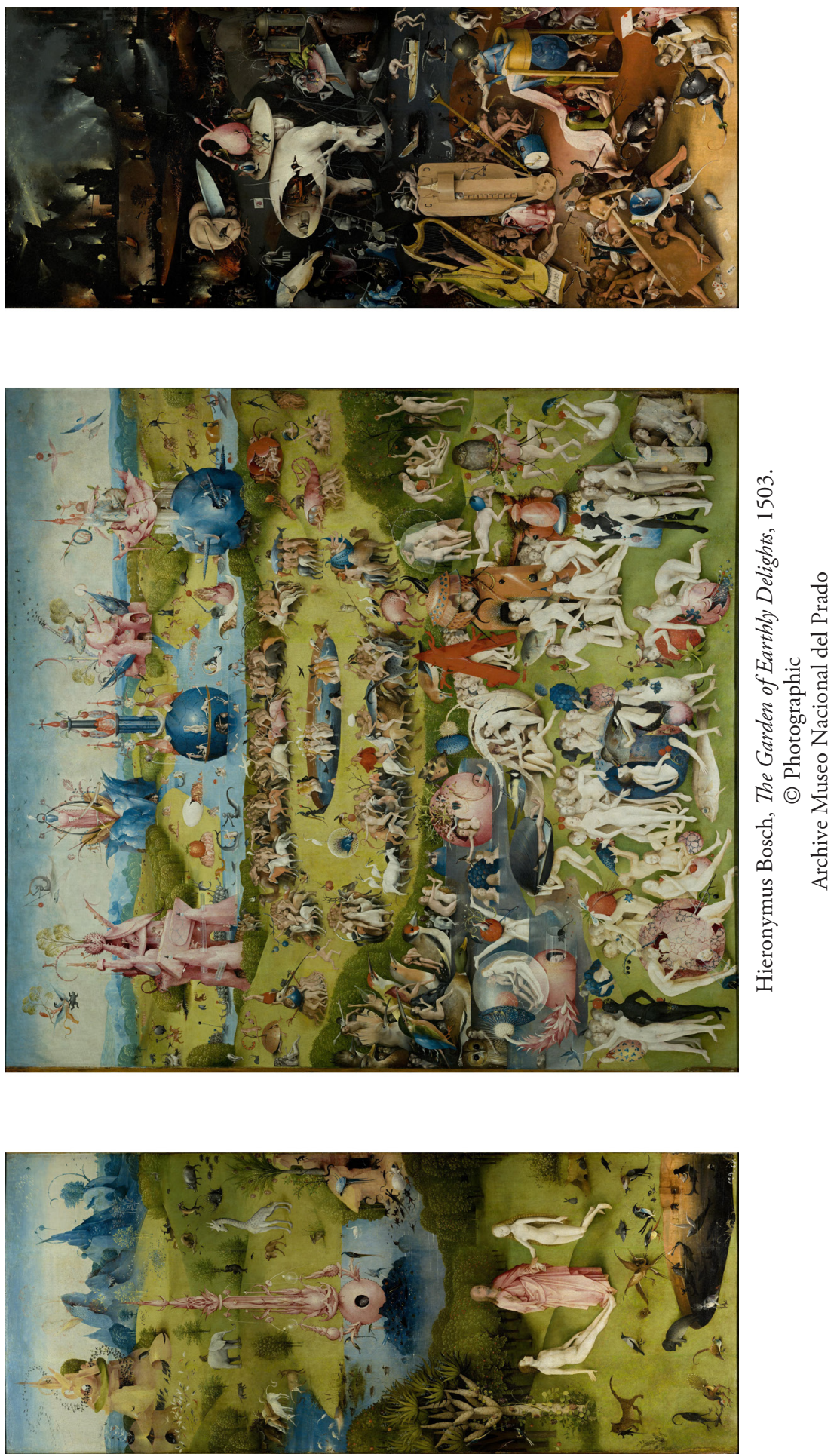


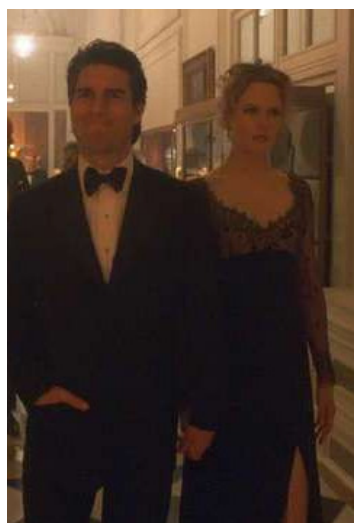

Bill and Alice Harford, new Adam and Eve.

S. Kubrick, Eyes Wide Shut, 1999.

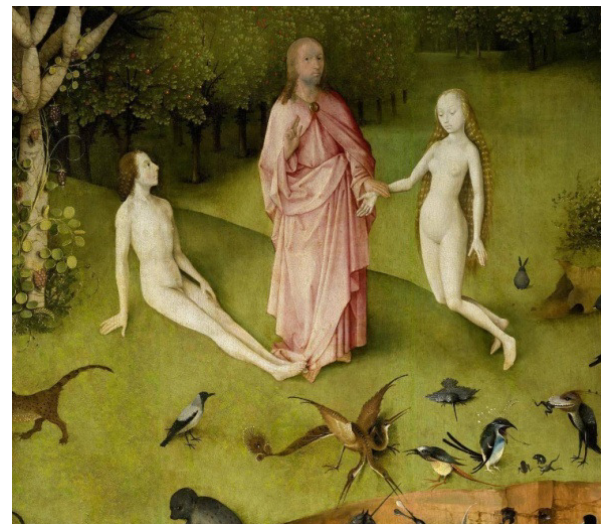

Adam and Eve, Paradise,

H. Bosch, The Garden of Earthly Delights, 1503. (C) Photographic

Archive Museo Nacional del Prado

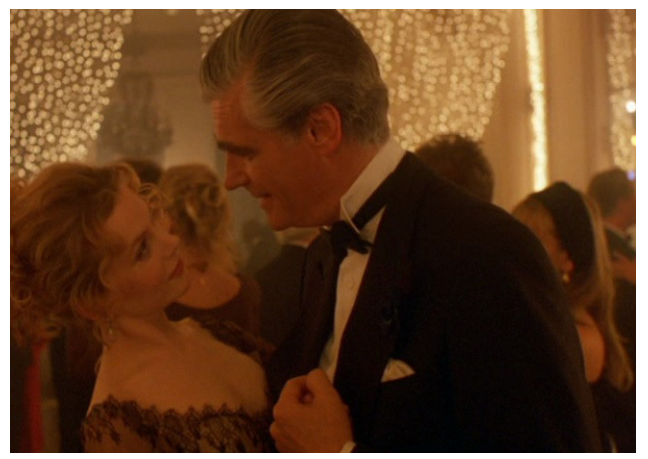

Alice's flirtation with Hungarian Szavost.

S. Kubrick, Eyes Wide Shut, 1999.

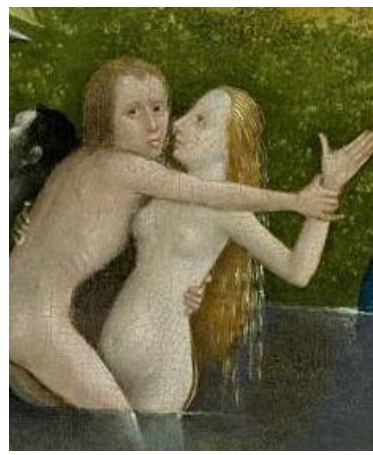

H. Bosch, Detail from the Humankind before the Flood. (C) Photographic Archive Museo Nacional del Prado 


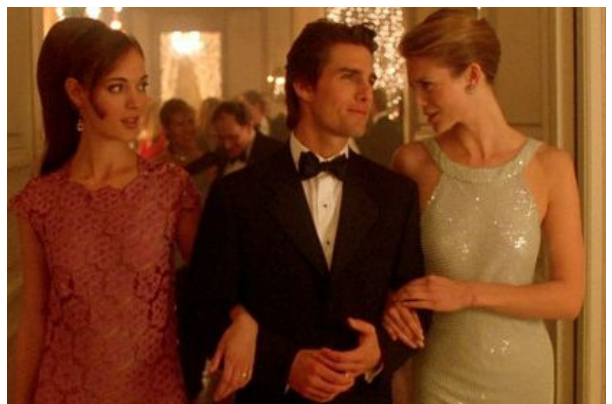

Bill's with two aggressive models "twined andundulating like two serpents".

S. Kubrick, Eyes Wide Shut

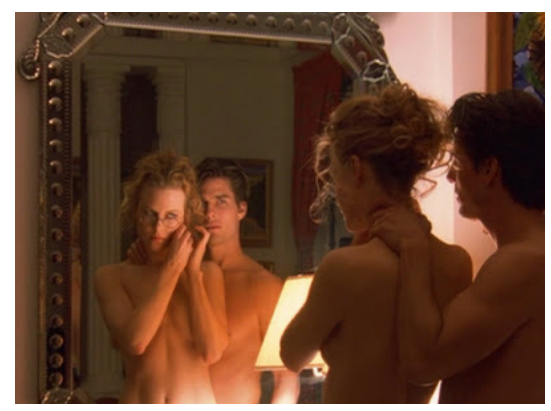

Alice (Lust) and Bill (Devil) in front of the mirror, before making love.

S. Kubrick, Eyes Wide Shut

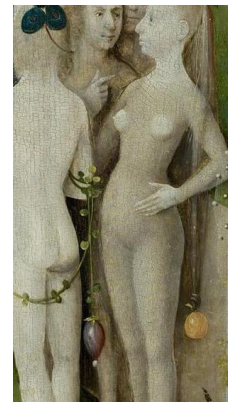

H. Bosch, Detail from the

Humankind before the Flood.

(C) Photographic

Archive Museo Nacional del Prado

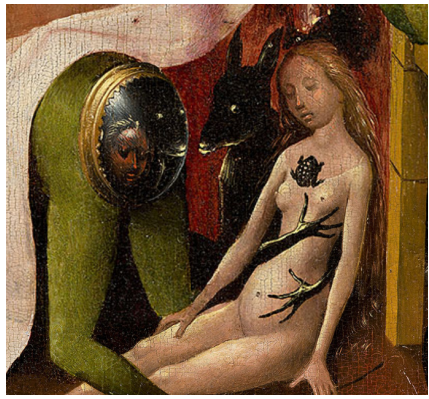

Woman (Lust) and Devil in front of the mirror, H. Bosch, Hell panel. (C) Photographic

Archive Museo Nacional del Prado 


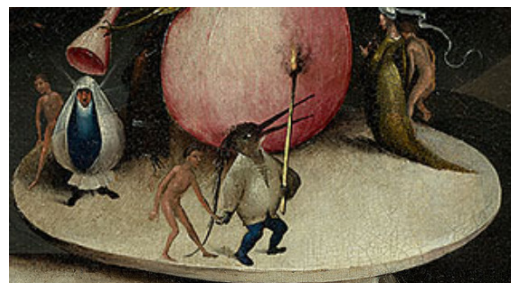

The motif of the circle,

H. Bosch, The Garden of Earthly Delights.

(C) Photographic

Archive Museo Nacional del Prado

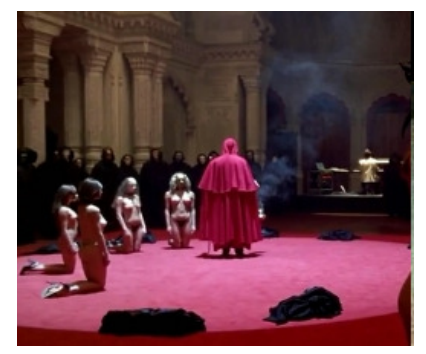

The circle as an important device of Kubrick's aesthetic.

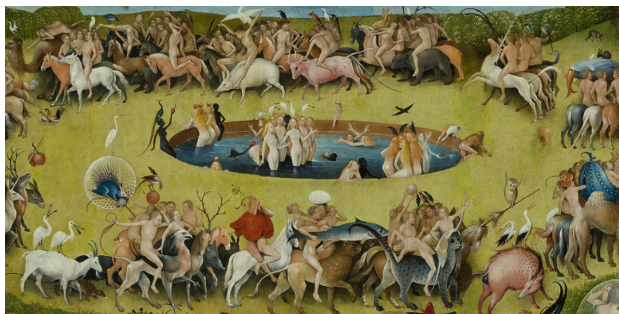

The motifs of riding in a circle and of riding wildly on animals as a metaphor for the sexual act.

$$
\text { (c) Photographic }
$$

Archive Museo Nacional del Prado

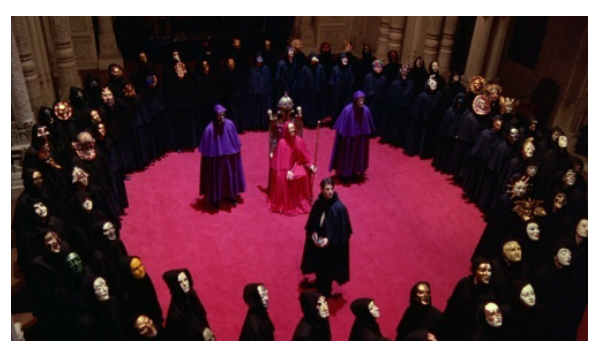

